\title{
APPLICATION OF COGNITIVE BEHAVIOR COUNSELING IN HELPING HANDLING THE CRISIS OF IDENTITY OF CLASS VIII STUDENTS OF STATE MIDDLE 1 BANYUWANGI
}

\author{
Atim Hariyadi $^{1 a}$, Jawahirul Kawakib ${ }^{2 b}$ \\ ${ }^{1}$ lecturer in history education at the PGRI Banyuwangi University \\ ${ }^{2}$ Guidance And Counseling Study Program at PGRI University Of Banyuwangi \\ University \\ aatimhariyadi@unibabwi.ac.id \\ bjawahirulkawakib@gmail.com
}

\section{ARTICLE HISTORY}

Received : 18-11-2019

Revised : 19-12-2019

Accepted : 6-03-2020

KEYWORDS

Behavioral Cognitive

Counseling;

Identity Crisis;

Helping Handling;

\section{ABSTRACT}

This research aims to help deal with the identity crisis experienced by VIII grade students of SMP Negeri 1 Banyuwangi. The research carried out is a guidance and counseling action research in which the research was carried out in two cycles. The subjects consisted of five classes, each consisting of 30 students so that the total number was 150 people. There are nine students who show the behavior of adolescents who experience identity crisis seen based on the percentage of the results of the questionnaire and direct observation, and the nine students are given the form of cognitive behavioral counseling. In this study, in the first cycle an increase was obtained, but only two students achieved criteria above $80 \%$, while seven students had not achieved a significant improvement. So that the second cycle is held, the overall student reaches an increase of up to $80 \%$ and above. The results of the analysis showed that the effort to overcome the identity crisis experienced by students by using cognitive behavioral counseling services in eighth grade students of SMP Negeri 1 Banyuwangi, there was a change in student behavior toward more positive individuals and groups.

\section{INTRODUCTIONS}

The development of an increasingly modern era, especially in the era of globalization as it is now demanding high quality human resources. Improving the quality of human resources is an absolute prerequisite for achieving development goals. One vehicle to improve the quality of human resources is education.

Education is a conscious effort to develop the potential of human resources through teaching activities. National Education System Law No. 20 of 2003, states, that the purpose of national education is to educate the life of the nation and develop Indonesian people as a whole, namely people who are devoted to God Almighty and virtuous character, have knowledge and 
skills, physical and spiritual health, a steady and independent personality and responsibility social and national responsibility.

Education in the broadest sense is the assistance or assistance given by one person to others to develop and function the spiritual (mind, taste, intention, creativity and conscience) of human and physical (sensory and skills) of humans in order to increase their knowledge insight. So education is not enough to focus on cognitive aspects alone but also non cognitive aspects. Both of these aspects have a considerable influence on the development of students. Cognitive education develops intellectual aspects, while non cognitive aspects help develop attitudes and skills.

As it is known that human behavior is influenced by two major factors namely internal factors and external factors. External factors include the community, family and school. In addition to playing a role as an input provider in developing education, it also helps provide learning facilities and infrastructure. Whereas the family acts as a foundation for children. Gunarsa (2002) states that, the family is the main source of education, because all the knowledge and intelligence of human intellect is first obtained from parents and family members themselves. In addition to the family as a place for children's education, schools play a role in continuing family education by providing knowledge and skills through academic and non-academic education. Thus education is carried out in three places to complement each other. In the SPN RI Law No.20 of 2003 Chapter I General Provisions paragraph 2 of the Education system stated that, all educational processes that aim to create an atmosphere of learning and learning process so that students actively develop their potential to have religious spiritual strength, self-control, personality, intelligence, noble character, and skills needed by himself, society, nation and country.

The facts on the ground indicate that schools prioritize the value of learning / academic results rather than personality development. Requirements for entering school at certain educational levels use UAN (National Final Examination) scores, TPA selection (Academic Potential Test), and other academic requirements. Rarely do we hear of schools that use personality as a requirement to be accepted as a new student at a particular school. As a result, many schools only emphasize on how to improve children's academic grades.

The subsequent impact is that many children are given tutoring or tutoring, both conducted in school and outside of school; holding competitions to increase academic achievement such as olympiad mathematics, physics, biology, and various other types of academic competitions.

As a result of the imbalance of the two aspects of education, children seem to be smart but arrogant and leave the emotional aspect. Goleman (1998) states that a person's success in life, in this case the success of positive social behavior is not only determined by intellectual intelligence alone but is much influenced by emotional intelligence. There is plenty of evidence to show that people who are emotionally capable of managing feelings well, and who are able to read and deal with the feelings of others effectively have an advantage in life. As is well known that, the integrity 
of HR lies not only in intellectual intelligence, but also social and emotional intelligence. The success or achievement achieved by human global society is not solely determined by intellectual intelligence but also by perseverance, commitment, motivation, sincerity, discipline and work ethic, the ability to empathize, and to interact.

So, social behavior plays an important role in life. This is one of the non-cognitive aspects that is often forgotten. Indications of good social behavior are such as courtesy, ability to empathize, like to work together, help others, do not force the will on others, will get good adjustments in society and can be accepted by the community and the creation of harmonious relationships between people. Conversely, people who are intellectually intelligent but do not know how to get along, are selfish, want to win themselves, do not respect others, will not be well received by society in their relationships (Pujiati: 2019).

In general, the school is an educational environment consisting of various individuals with all the uniqueness and differences. This is very possible for children to be able to develop their behavior because children will interact with many different people and they will learn to accept these differences. As is well known that in schools there are still many students who have low behavior, both in the classroom and outside the classroom. To overcome this behavior the teacher has made efforts aimed at fostering students. However, it seems that the teacher's coaching towards these students does not work optimally because children continue to display deviant behavior.

Deviant behavior caused by two factors, namely internal factors and external factors. Internal factors are factors that originate from within a person such as unmet needs, certain motives, anxiety, inner conflict, slow learning ability, negative self-concept (easily anxious, shy, and arrogant). Children who have problematic behavior due to personal disruption.

External factors are factors that cause external factors such as the geographical and social environment (family, school and community). These outside factors are experiences gained from the natural environment and education. Uncoded social environment is the main source of the formation of deviant behavior, such as the association of children outside the home or community. Gunarsa

(2002) states that children who are overly loved, protected and spoiled by their families cause the child to be ashamed, anxious, afraid and behave disobediently, so the school will show the same symptoms as at home, not complying with the rules and commands, like to attract attention and control other people or other children's play equipment. The description obtained from these statements is that unnatural affection from both parents can cause deviant behavior in children. Family disharmony such as incomplete family divorce, the absence of parents for a long time in a planned or continuous manner can trigger deviant behavior in children. The opinions above provide an indication that internal and external factors are very color to one's behavior. The 
concept of self as one of the internal factors and parenting as an external factor greatly influences the formation of deviant behavior trends.

The concept of self as a center of behavior in individuals will certainly determine the pattern of individual behavior in dealing with the surrounding environment and how to interact with others. Students with negative self-concepts tend to have negative reactions to themselves, friends, teachers and their education at school, and vice versa. For example, if it is not firmly embedded in positive self-concepts such as responsibility in learning and following education with enthusiasm, students will be easily influenced by peers who tend to deviate, for example ditching, not doing the tasks given, or deviant behaviors like fighting and breaking the rules. The opposite will be shown by students with positive self-concepts, which in the care of parents instilled positive self-concepts such as responsibility, then the student concerned will follow the lesson carefully, obeying any applicable regulations and will not be easily affected by the environment tend to deviate. The concept of self is a statement about "who I am" that will determine how an individual behaves and behaves in his daily life, and how the individual accepts or rejects various influences from his environment.

In the literature entitled Parental Delinquency Causes of Juvenile Delinquency, it is said that juvenile delinquency, aggressive behavior and deviant behavior are identified as the three most common forms of psychosocial problems experienced by adolescents. According to the development perspective which focuses a lot on adolescent development, namely the psychosocial development theory from Erikson (1968), psychosocial problems in adolescents can be attributed to the obstacles in dealing with the issue of psychosocial development in the teenage period, namely the identity crisis.

Then this research was conducted to obtain an effective counseling intervention model to deal with adolescent identity crisis and psychosocial problems. In this study subjects will be given treatment in the form of group counseling to help overcome their identity crisis. Group counseling aims to discuss individual problems. Each member addresses the problem, but not all group members need to. If a problem has been raised, it is necessary to discuss and deliberate on the issue of who first discussed it. Ingroup counseling

thisstudents will be able to try out their attitudes and ideas. Acceptance and experiences and attitude changes that are tried will strengthen the motivation to make changes in him. Furthermore, group experience will improve communication skills with others and will developinterpersonal relationships genuine. Acceptance and understanding from friends in the group produces a sense of security and a sense of unity that will support the process of introspection and expression of deep feelings. This is expected to develop the courage of students / individuals to try to solve personal problems and emotional conflicts inside and outside themselves to help resolve identity crises. However, solving an identity crisis is not enough just through group counseling. Furthermore, 
students who have not been able to resolve their identity crisis in group counseling will be conducted cognitive behavioral counseling which is expected to be able to solve the problem of student identity crisis.

\section{MATERIALS AND METHODS RESEARCH LOCATION}

\section{This research is an action research counseling (Action Research in Counseling).} This research was conducted at SMP Negeri 1 Banyuwangi.

This research was designed in two cycles, each cycle consisting of four stages. This research cycle follows the Arikunto pattern (2008) which consists of four stages, namely (1) the planning stage, (2) the implementation phase, (3) the observation and evaluation stage, and (4) the reflection phase. Data on identity crises was collected using a questionnaire method, supplemented by data from observation and interview methods.

The research subjects were Grade VII students of SMP Negeri 1 Banyuwangi. The reason for taking subjects in class VII is because of the results of the initial study, many symptoms are shown by students as traits of adolescents who experience an identity crisis. This is shown by a number of symptoms, namely some students who have not been able to appreciate their classmates, some students who are closed in exploring themselves and some other students who are rather difficult to make friends well or lack concentration in following the lessons and tend to violate school rules.

The data of this study were analyzed by descriptive analysis. Descriptive analysis is used to analyze by comparing the percentage achieved before and after the action.

The formula used is as follows:

$$
\begin{aligned}
& P=\frac{X}{S M I} \times 100 \% \\
& \mathrm{P}=\text { Percentage of Achievement } \\
& \mathrm{X}=\text { Actual Score }
\end{aligned}
$$$$
\text { SMI = Maximum Score }
$$

The result of identity crisis experienced by students in descriptive statistics with qualifications using the guideline conversion conversion guidelines with the criteria of $90 \%-100 \%$ (Very High), 80\% - 89\% (High), 65\% - 79\% (Fair), 55\% - 64\% (Low), 0\% - 54\% (Very Low). This research is said to succeed quantitatively if it is at achieving a percentage above $80 \%$.

While qualitative analysis means the research is said to be successful if students are able to show behavior that is a) willing to be open in exploring and understanding self-concepts, b) already expressing feelings so as not to cause conflict, c) able to tolerate a variety of self and others' expressions, d) able to choose and adjust themselves in existing social groups, e) able to avoid 
themselves in the formation of deviant behavior and aggressive behavior, and f) able to apply the abilities, opportunities, and interests of existing talent well.

\section{RESULTS AND DISCUSSIONS}

\section{A. Research Results The}

results of the study explain that an increase in alleviating student problems indicates that the identity crisis experienced by students has begun to be overcome as seen from the initial spread score and the score in cycle I.

Based on the results of the action in cycle I, it actually happened increasing students' ability to overcome psychosocial problems that cause identity crises. Of the nine students handled, it turned out that two students had experienced an increase in the high category. While the other seven students, although experiencing an increase, are still not able to solve their own problems well enough.

The percentage increase is shown in table 1 and graph 1 as follows:

Table 1. Results of Improvement of Problem Reduction (Cycle I)

\begin{tabular}{lccccccc}
\hline No & Nama & $\begin{array}{l}\text { Initial } \\
\text { Score } \\
\text { (SA) }\end{array}$ & $\%$ & $\begin{array}{c}\text { Cycle } \\
\text { I (S1) }\end{array}$ & $\%$ & Category & $\begin{array}{c}\text { Increase } \\
\% \\
(\mathbf{P})\end{array}$ \\
\hline $\mathbf{1}$ & ASK & 142 & 63,3 & 184 & 81,7 & High & 29,5 \\
$\mathbf{2}$ & BSA & 145 & 64,4 & 182 & 80,9 & High & 25,5 \\
$\mathbf{3}$ & KAG & 141 & 62,6 & 155 & 68,8 & Fair & 9,9 \\
$\mathbf{4}$ & SSG & 135 & 60 & 141 & 62,6 & Low & 4,5 \\
$\mathbf{5}$ & DYG & 135 & 60 & 142 & 63,3 & Low & 5,2 \\
$\mathbf{6}$ & MDW & 145 & 64,4 & 157 & 69,7 & Fair & 8,2 \\
$\mathbf{7}$ & BRA & 141 & 62,6 & 145 & 64,4 & Low & 2,8 \\
$\mathbf{8}$ & ETW & 142 & 63,3 & 157 & 69,8 & Fair & 10,5 \\
$\mathbf{9}$ & TSA & 135 & 60 & 145 & 64,6 & Low & 7,4 \\
\hline
\end{tabular}




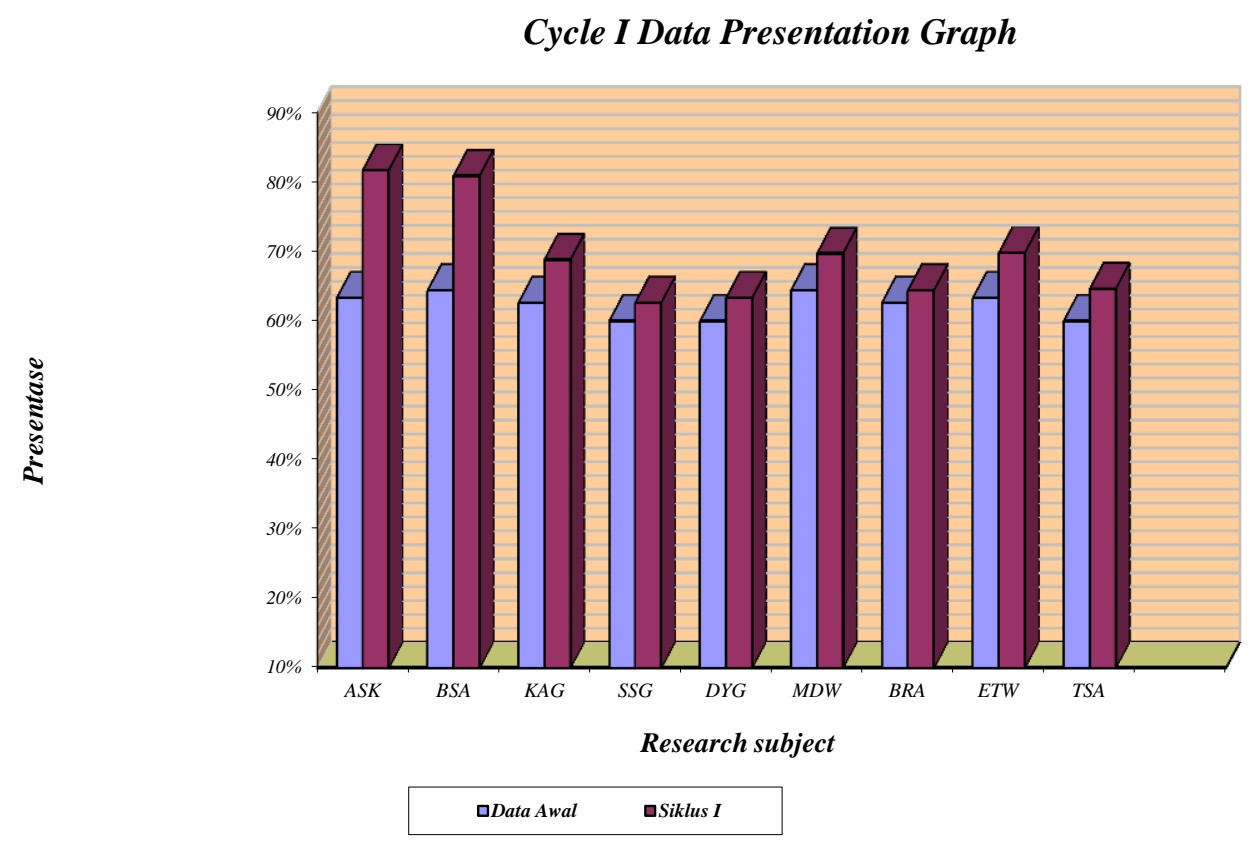

\section{Graph 1. Percentage of Results of Improvement in Problem Reduction (Cycle I)}

From the results of an intensive approach to the seven students and further observations can be obtained information, that they still do not want to be truly completely open with the problems being faced so it is rather difficult to direct and provide positive and negative concepts to a choice in the process of alleviating their problems.

Based on this information, action research needs to be continued in the second cycle to anticipate deficiencies in the first cycle of research, so that the problems that cause students' identity crises can be alleviated according to the expected criteria.

Each student is handled again handled in group dynamics to help them communicate and make friends correctly, also carried out direct interviews and invite them to act in a better direction than before by providing positive concepts and explaining negative concepts so that they are not wrong in take steps or decide something in his life later. Here the counselor or tutor applies a cognitive approach to behavior by inviting students to be able to think rationally. Things such as: whether the student will forever take the easiest shortcut in overcoming the problem? What if you do not understand with certain subjects, how to overcome them only run away or play truant? Is there no other way? What if offended by someone's words must be directly fought? The question is examined positively and rationally by describing the good and bad of a decision that must be they took. If this has been done then they will be able to act according to the demands of their developmental duties as teenagers. 
Besides that they are invited to understand and develop positive ideas such as the benefits of studying diligently, speaking polite words, not holding grudges, the benefits of confidence, knowing that failure is the beginning of success, being able to maintain their emotions and getting to know themselves so they can make decisions well. All of that will result in an understanding of oneself, so that they will respect themselves and others more. Evaluations from the preliminary data to Cycle II are evaluated through descriptive statistics with percentage techniques. By taking the same procedure, the evaluation results are obtained as in the following table 2:

Table 2. Results of Improvement of Problem Eradication (Cycle II)

\begin{tabular}{lcccccccc}
\hline & & \multicolumn{7}{c}{ Eradication Problem } \\
\cline { 3 - 7 } No & Name & \multicolumn{2}{c}{ Early } & \multicolumn{2}{c}{ Cycle I } & \multicolumn{2}{c}{ Cycle II } & \multirow{2}{*}{ Increase \% } \\
& & Skor & $\%$ & Skor & $\%$ & Skor & $\%$ & \\
$\mathbf{1}$ & ASK & 142 & 63,3 & 184 & 81,7 & 184 & 81,7 & 29,5 \\
$\mathbf{2}$ & BSA & 145 & 64,4 & 182 & 80,9 & 182 & 80,9 & 25,5 \\
$\mathbf{3}$ & KAG & 141 & 62,6 & 155 & 68,8 & 178 & 80,1 & 26,2 \\
$\mathbf{4}$ & SSG & 135 & 60 & 141 & 62,6 & 182 & 80,9 & 33,3 \\
$\mathbf{5}$ & DYG & 135 & 60 & 142 & 63,3 & 179 & 80,5 & 32,5 \\
$\mathbf{6}$ & MDW & 145 & 64,4 & 157 & 69,7 & 185 & 82,2 & 27,5 \\
$\mathbf{7}$ & BRA & 141 & 62,6 & 145 & 64,4 & 193 & 85,7 & 36,8 \\
$\mathbf{8}$ & ETW & 142 & 63,3 & 157 & 69,8 & 190 & 84,4 & 33,8 \\
$\mathbf{9}$ & TSA & 135 & 60 & 145 & 64,6 & 182 & 80,8 & 34,8 \\
\hline
\end{tabular}

Based on the results of monitoring of cognitive behavioral counseling in cycle II, the results of these actions have improved implementation, compared to cycle I. In this case the counselor has sought to optimize the application of cognitive behavioral counseling whose implementation has not been optimal in cycle I. The changes shown by students in this cycle II, the students keep showing $\mathrm{n}$ positive symptoms in acting, interacting daily and in learning. In general, students have shown a better attitude toward them. They have tried to speak politely, start to maintain emotions, do not make a fuss in the classroom and no longer skipping school. Judging from table 2 it can be stated that the increase in each individual revolves around high criteria. This means that the use of group dynamics will help students deal with problems that cause them to be misdirected and thus experience an identity crisis. Final data on the results of the study can be seen as the following graph: 


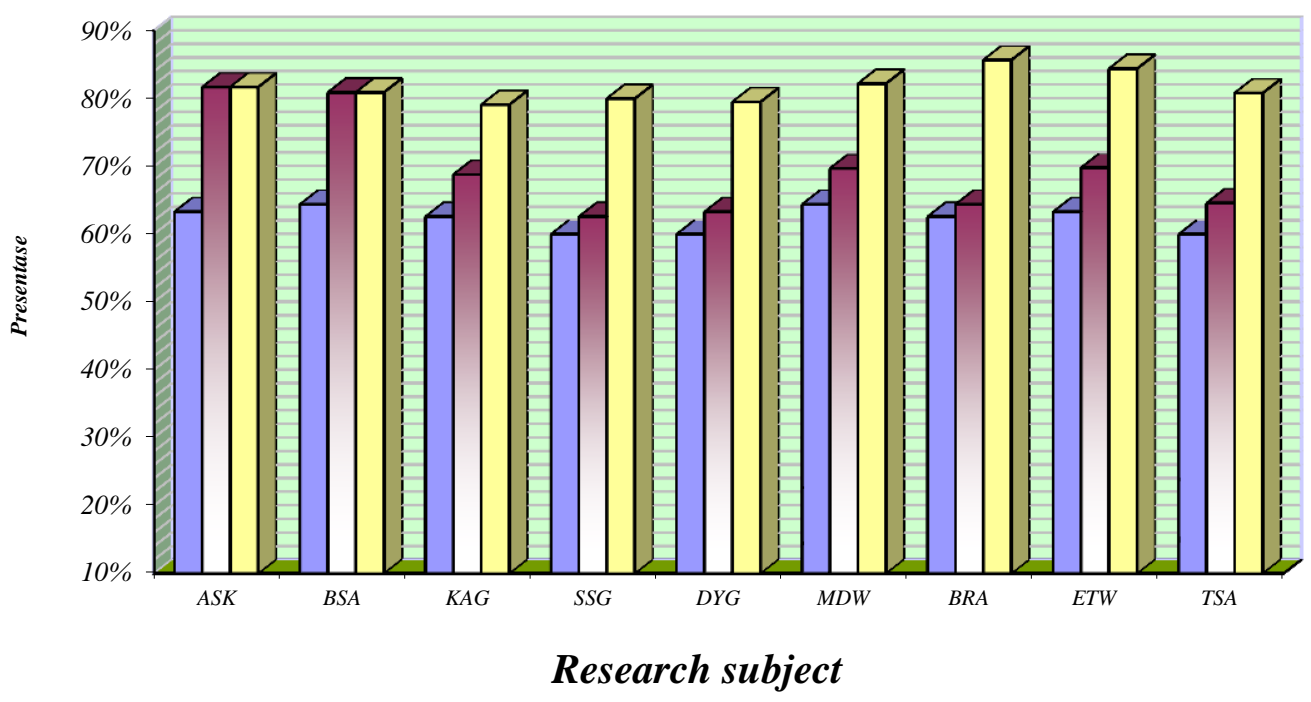

\begin{tabular}{|ll|}
\hline 口Data Awal $\quad$ DData Siklus I $\quad$ Data Siklus II \\
\hline
\end{tabular}

\section{Graph 2. Graph of Results of Improvement in Problem Reduction (Cycle II)}

\section{Discussion}

Based on the results of the study note that the crisis of student identity after being provided with cognitive behavioral counseling services turned out to be alleviated. From the results of evaluating actions in the first cycle and in the second cycle, it can be seen that there is a high change in the way students deal with the problems that are being experienced. This shows that effective behavioral cognitive counseling is used to help in overcoming student identity crises. In this study it has been seen that cognitive behavioral counseling is used appropriately in helping students to solve problems to exceed $80 \%$, which slowly results will be seen in students by showing behavior that is willing to open in exploring and understanding self-concepts, able to express feelings so as not to cause conflict, able to tolerate a variety of expositions of oneself and others, able to choose and adapt to existing social groups, able to avoid themselves in the formation of deviant and aggressive behavior, and able to apply the abilities, opportunities, and interests of existing talent nicely. The counseling process in this counseling activity helps students to change bad behavior, unfavorable study habits, negative student habits, and the habit of running away or looking for shortcuts in overcoming problems can be reduced. 


\section{CONCLUSION}

Based on research results and discussion, it can be concluded that there is an increase in students' understanding of the problem that causes students to take the right decisions so that the alleviation of problems that cause an identity crisis can be seen from the results of descriptive data analysis namely an increase ranging from $25.5 \%$ to $36.8 \%$ with the category high. This also shows that cognitive behavioral counseling has been successfully used to help overcome the identity crisis of eighth grade students of SMP Negeri 1 Banyuwangi.

In accordance with the findings in this study, students should be more open when experiencing problems. If you cannot ask for help or advice from friends, the supervisor or homeroom teacher will certainly be happy to help. It is also expected that students begin to get used to always considering the good and bad of a decision before it is implemented so that it does not go wrong and lead to an identity crisis. Thus students are able to learn from an error made previously to make themselves try harder and be more careful in making decisions.

Therefore, it is important for school counselors and supervisors that behavioral cognitive counseling is more developed so that this counseling can be applied on an ongoing basis with the aim of knowing the development of both problematic and non-problematic students in order to provide comprehensive counseling services to other students who are requires, not only students who experience an identity crisis. And related to student achievement in school, curriculum developers at school need to understand that the ability to solve problems for students is an important role in determining comfort and motivating students to learn well without being burdened with problems without leading to negative actions. So it is important for schools to maintain, shape and improve harmony and a sense of family in the school environment and always hold monitoring of student development.

\section{REFERENCES}

Arikunto, Suharsimi. 2006. Research Procedures; A Practical Approach. Jakarta: PT. RinekaCipta.

Corey, Gerald, (E. Koeswara. Translator). 2010.Theory and Practice of Counseling and Psychotherapy. Bandung: PT.Refika Aditama.

Erikson, Erik H. 1968. Identity: Youth and Crisis. New York: WW Norton \& Company Inc.

Gunarsa, Singgih D. 2002. Child and Youth Development. Jakarta: BPK Gunung Mulia.

Iskandaryah, Aulia. 2005. Teens and their Problems, Papers, Pajajaran University, Bandung, downloaded from http://www.digilib.unpad.ac.id accessed in October 2012.

Lestari, Sri. 2012. Family Psychology. Jakarta: Kencana Media Perdana Group. 
Nurihsan, Ahmad Juntika. 2009. Guidance and Counseling in VariousBackgrounds Life. Bandung: PT. Refika Aditama.

Nurkancana. 1990. Individual Understanding. Surabaya: PT Usaha Nasional.

Partono 2004. The Effect of Group Counseling Services on the Development of Emotional Intelligence (Experimental research in SMK Negeri 8 Semarang Students). Essay. BK, FIP, UNNES were downloaded from http://www.digilib.unnes.ac.id accessed in January 2013.

Prayitno and Erman Amti. 1994. Fundamentals of Guidance and Counseling. Jakarta: Rineka Cipta.

Pujiati, I. 2018. Pengaruh Konseling Cognitive Behavior Teknik Cognitive Restructuring Untuk Mereduksi Kecemasan Sosial Siswa. Prosiding Seminar Nasional FKIP Univeristas PGRI Banyuwangi.

Sukardi, Dewa Ketut. 2008. Introduction to the Implementation of Guidance and Counseling Programs in Schools. Jakarta: Rineka Cipta.

Surbakti, EB. 2008. Parental Delinquency Causes Juvenile Delinquency. Jakarta: PT. Gramedia Main Library.

National Education System Law No. 20 of 2003

Uno, Mien R. 2009. Etiquette for Teens. Jakarta: PT. Gramedia Main Library. 